\title{
Effect of Serum Zinc Concentration Amongst Pregnant Women in Mosul
}

\author{
Bassam E. Hanna \\ Luma M. Tohala \\ Wael Abd-Alkader \\ Department of Biochemistry \\ Ninevah College of Medicine \\ University of Mosul \\ Department of Chemistry \\ College of Science \\ University of Mosul
}

(Received 26/10 / 2010; Accepted 6/6 / 2011 )

\begin{abstract}
The study was conducted in Mosul during the period from february to april 2009 including non-married and pregnant group composed of 35 and 105 apparently healthy women respectively. Pregnant group were subdivided equally according to their trimester into three subgroups, women in second and third trimester are having ferrous sulphate in their ingestion. Serum zinc measurements were done for these groups of women.the results showed that serum zinc concentration start to reduce significantly during second trimester continue to decline in third trimester in comparison with non-married group. Therefore, it is recommended to measure serum zinc during pregnancy with the use of optimal dose of zinc supplemental therapy.
\end{abstract}

Keywords: Zinc, Pregnancy, Trimester.

\section{تأثير تركيز الخارصسن عل نساء الموطل الحوللل}

\section{الماذص}

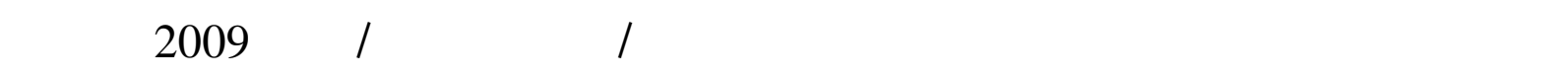

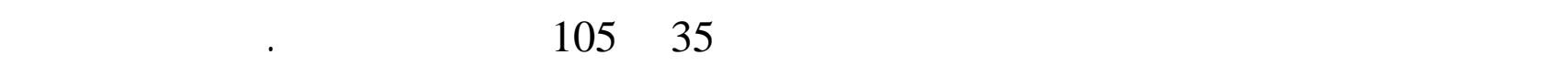

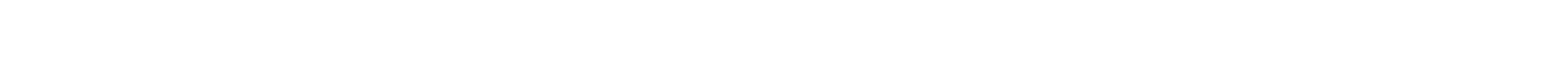
مُّه يتناولن كبريتات الحديدوز وم قيلال تركيز الخارصين لمصل الهم لهذه المجلمبع من النساء.

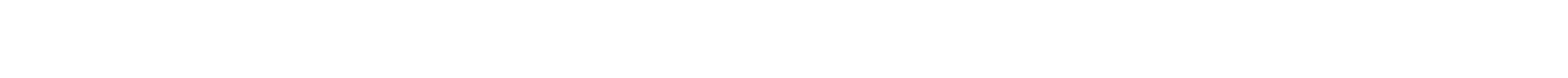

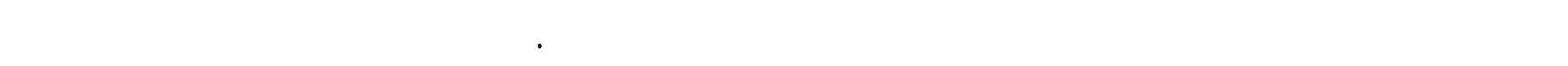
لمصل الدم أثناء الحطل ولستعمل علاج الخارصين الداعم بجرع مثالية. 


\section{INTRODUCTION}

Zinc (Zn) is one of the trace elements necessary for health and growth. It is present in the biological fluids as $\mathrm{Zn}^{+2}$ that has many biological functions related to its main function as a co-factor in more than 300 enzymes(Michaelsen et al., 1994; Burits et al., 2006). Zinc ion also participates in the distribution of proteins and gene expression, stabilizes the structure of protein and nucleic acids, preserves the intracellular organelles situation and plays a role in the transfusion and immunological responses(Michaelsen et al., 1994; Burits et al., 2006; Kaltenberg et al., 2010).

Evidences suggest that Zn deficiency is one of the important problems within the developed and developing countries (Sanders and Sandstead, 1991) and it is among the ten most important factors that lead to increased morbidity and mortality in developing countries (Bahl et al., 2001; Shrimpton, 2005). Its deficiency during pregnancy has been suggested to be associated with adverse maternal and fetal outcome (Hickory et al., 1979; Yasodhara et al., 1996; Raman and Shatrugna, 2001; Pathak et al., 2008).

The objective of this study is to demonstrate the possible effect of pregnancy on serum Zn level in Mosul city.

The study was conducted during the period from february to april 2009, subjects enrolled in this study were volunteers attending a private laboratory in Mosul include 140 women, divided into two groups (I and II).

Group I considered as control composed of 35 apparently healthy non-married women, their ages ranged from (18-38) years.

Group II composed of 105 apparently healthy pregnant women, their ages ranged from (18-40) years. According to pregnancy trimester this group was subdivided into three subgroups:

Subgroup A composed of 35 apparently healthy women in their first trimester of pregnancy, their ages ranged from (18-39) years.

Subgroup B composed of 35 apparently healthy women in their second trimester of pregnancy, their ages ranged from (18-40) years.

Subgroup C composed of 35 apparently healthy women in their third trimester of pregnancy, their ages ranged from (19-37) years.

\section{Apparatus}

The measurement was done by atomic absorption spectrometry Pye Unicom P SP9 instrument (England) using Zn metal (purity 99.9\%) dissolved in concentrated hydrochloric acid $(11 \mathrm{~N})$ to obtain a stock Zn solution (1000 ppm), then diluted to 1, 2, 3, 4 and $5 \mathrm{ppm}$ to draw the standard curve used for calculation of Zn concentration in this study.

\section{RESULTS AND DISCUSSION}

The results were statistically evaluated by standard statistical methods including mean $(\overline{\mathrm{X}})$, standard deviation (SD), range (minimum-maximum), linear regression analysis (Pearson correlation coefficient r), student's t-test (Khachatryan and Nikos, 1998 ; Jones, 2002; Chap, 2003) with computer software programs including Microsoft excel 2007 and statistical package for the social sciences (SPSS) 11.5 (Joaquim, 2007). 
Table 1 show serum Zn concentration in group I and II members. The $\overline{\mathrm{X}} \pm \mathrm{SD}$ in group I and II were $12.09 \pm 1.16$ and $9.72 \pm 1.84 \mu \mathrm{mol} / \mathrm{L}$ respectively with significant lower value in group II compared with group I ( $<<0.001$, Table1, 2, Fig. 1).

Serum $\mathrm{Zn}$ concentration in group I showed a normal distribution pattern with the reference range calculated as $\overline{\mathrm{X}} \pm 2 \mathrm{SD}$ was $9.78-14.41 \mu \mathrm{mol} / \mathrm{L}$ (Fig 2).

The $\overline{\mathrm{X}} \pm$ SD of the age in subgroup A, B and C were 23.9 $\pm 5.3,25.5 \pm 4.9$ and $24.7 \pm$ 4.1 years respectively with no significant differences between them $(p>0.05)$ or in comparison with group I ( $\mathrm{p}>0.05$, Table 2).

The $\overline{\mathrm{X}} \pm \mathrm{SD}$ of serum Zn concentration in subgroup A, B and C were $11.53 \pm 1.28,9.12$ \pm 1.35 and $8.49 \pm 1.26 \mu \mathrm{mol} / \mathrm{L}$ respectively with significant lower value in subgroup $\mathrm{B}$ and C compared with subgroup A ( $<<0.001$, Fig 3 ) and in subgroup C compared with subgroup B (p < 0.05, Fig. 3). In comparison with group I; both subgroup B and C have significant lower value $(\mathrm{P}<0.001$, Table 1,2 ; Fig 3$)$ with no significant difference in subgroup A ( $>$ 0.05, Table 1, 2; Fig. 3).

The $\overline{\mathrm{X}} \pm \mathrm{SD}$ of the number of deliveries in group II and in subgroups $\mathrm{A}, \mathrm{B}$ and $\mathrm{C}$ were $2.13 \pm 1.81,2.23 \pm 1.72,2.11 \pm 1.84$ and $2.13 \pm 2.17$ respectively (Table 2 ) with no significant differences between subgroups ( $\mathrm{p}>0.05)$.

In group II and in subgroups B and C, a significant negative correlation ( $\mathrm{p}<0.001)$ found between duration of pregnancy and serum Zn concentration (Fig 4, 5, 6 respectively) with r-value $=-0.729,-0.615$ and -0.676 respectively.

In group I and II and in subgroups A, B and C; no significant correlation exist between the age and serum Zn concentration. Furthermore, in group II and in subgroups A, B and C; no significant correlations exist between the number of deliveries and serum $\mathrm{Zn}$ concentration.

Table 1: Serum Zn concentration( $\mu \mathrm{mol} / \mathrm{L})$ in group I and II members .

\begin{tabular}{|c|c|c|c|c|c|c|c|c|}
\hline \multirow{5}{*}{\multicolumn{2}{|c|}{$\begin{array}{c}\text { Group I } \\
\text { Non Married } \\
\mathbf{n}=35\end{array}$}} & 9.05 & 11.21 & 11.21 & 11.75 & 12.29 & 12.84 & 13.38 \\
\hline & & 10.13 & 11.21 & 11.75 & 11.75 & 12.29 & 12.84 & 13.38 \\
\hline & & 10.67 & 11.21 & 11.75 & 12.29 & 12.84 & 13.38 & 13.92 \\
\hline & & 10.67 & 11.21 & 11.75 & 12.29 & 12.84 & 13.38 & 13.92 \\
\hline & & 10.67 & 11.21 & 11.75 & 12.29 & 12.84 & 13.38 & 13.92 \\
\hline \multirow{15}{*}{$\begin{array}{c}\text { Group II } \\
\text { Pregnant } \\
\mathbf{n}=105\end{array}$} & \multirow{5}{*}{$\begin{array}{c}\text { Subgroup } \\
\mathbf{A} \\
\mathbf{n}=35\end{array}$} & 9.04 & 10.42 & 10.88 & 11.34 & 11.79 & 12.25 & 13.17 \\
\hline & & 9.96 & 10.42 & 10.88 & 11.34 & 11.79 & 12.25 & 13.63 \\
\hline & & 9.96 & 10.42 & 10.88 & 11.34 & 11.79 & 12.71 & 13.63 \\
\hline & & 9.96 & 10.42 & 10.88 & 11.34 & 11.79 & 12.71 & 14.09 \\
\hline & & 9.96 & 10.88 & 11.34 & 11.34 & 11.79 & 12.71 & 14.55 \\
\hline & \multirow{5}{*}{$\begin{array}{c}\text { Subgroup } \\
\text { B } \\
\mathbf{n}=35\end{array}$} & 6.75 & 7.67 & 8.13 & 9.04 & 9.50 & 9.96 & 10.42 \\
\hline & & 6.75 & 7.67 & 8.59 & 9.04 & 9.50 & 9.96 & 10.42 \\
\hline & & 7.21 & 7.67 & 8.59 & 9.04 & 9.96 & 9.96 & 10.42 \\
\hline & & 7.21 & 8.13 & 9.04 & 9.50 & 9.96 & 10.42 & 11.34 \\
\hline & & 7.67 & 8.13 & 9.04 & 9.50 & 9.96 & 10.42 & 12.71 \\
\hline & \multirow{5}{*}{$\begin{array}{c}\text { Subgroup } \\
\text { C } \\
\mathbf{n}=35\end{array}$} & 6.29 & 7.67 & 8.13 & 8.13 & 8.59 & 9.04 & 9.50 \\
\hline & & 6.29 & 7.67 & 8.13 & 8.13 & 8.59 & 9.04 & 9.50 \\
\hline & & 6.75 & 7.67 & 8.13 & 8.59 & 8.59 & 9.04 & 9.96 \\
\hline & & 7.21 & 7.67 & 8.13 & 8.59 & 8.59 & 9.04 & 12.25 \\
\hline & & 7.21 & 8.13 & 8.13 & 8.59 & 9.04 & 9.04 & 12.25 \\
\hline
\end{tabular}


Table 2: Comparison between parameters of group I and II.

\begin{tabular}{|c|c|c|c|c|}
\hline Parameter & $\begin{array}{c}\text { Group I } \\
\text { Non Married } \\
\mathbf{n}=35\end{array}$ & \multicolumn{3}{|c|}{$\begin{array}{c}\text { Group II } \\
\text { Pregnant } \\
\mathbf{n}=105\end{array}$} \\
\hline \multirow{3}{*}{ Age (Years) } & \multirow{3}{*}{$24.8 \pm 4.5$} & \multicolumn{3}{|c|}{$\begin{array}{c}24.7 \pm 4.8 \\
t=0.10 \\
p>0.05\end{array}$} \\
\hline & & Subgroup A & Subgroup B & Subgroup C \\
\hline & & $\begin{array}{c}23.9 \pm 5.3 \\
t=0.75 \\
p>0.05\end{array}$ & $\begin{array}{c}25.5 \pm 4.9 \\
t=0.64 \\
p>0.05\end{array}$ & $\begin{array}{c}24.7 \pm 4.1 \\
t=0.11 \\
p>0.05\end{array}$ \\
\hline \multirow{3}{*}{$\begin{array}{l}\text { Serum Zn } \\
(\mu \mathrm{mol} / \mathrm{L})\end{array}$} & \multirow{3}{*}{$12.09 \pm 1.16$} & \multicolumn{3}{|c|}{$\begin{array}{c}9.72 \pm 1.84 \\
t=7.18 \\
p<0.001\end{array}$} \\
\hline & & Subgroup A & Subgroup B & Subgroup C \\
\hline & & $\begin{array}{c}11.53 \pm 1.28 \\
t=1.92 \\
p>0.05\end{array}$ & $\begin{array}{c}9.12 \pm 1.35 \\
t=9.90 \\
p<0.001\end{array}$ & $\begin{array}{c}8.49 \pm 1.26 \\
t=12.43 \\
p<0.001\end{array}$ \\
\hline \multirow{3}{*}{$\begin{array}{l}\text { Number of } \\
\text { Deliveries }\end{array}$} & & \multicolumn{3}{|c|}{$2.13 \pm 1.81$} \\
\hline & & Subgroup A & Subgroup B & Subgroup C \\
\hline & & $2.23 \pm 1.72$ & $2.11 \pm 1.84$ & $2.13 \pm 2.17$ \\
\hline
\end{tabular}

Values are presented as $\overline{\mathrm{X}} \pm \mathrm{SD}$, $\mathrm{t}$ and $\mathrm{p}$-values in comparison with group I 


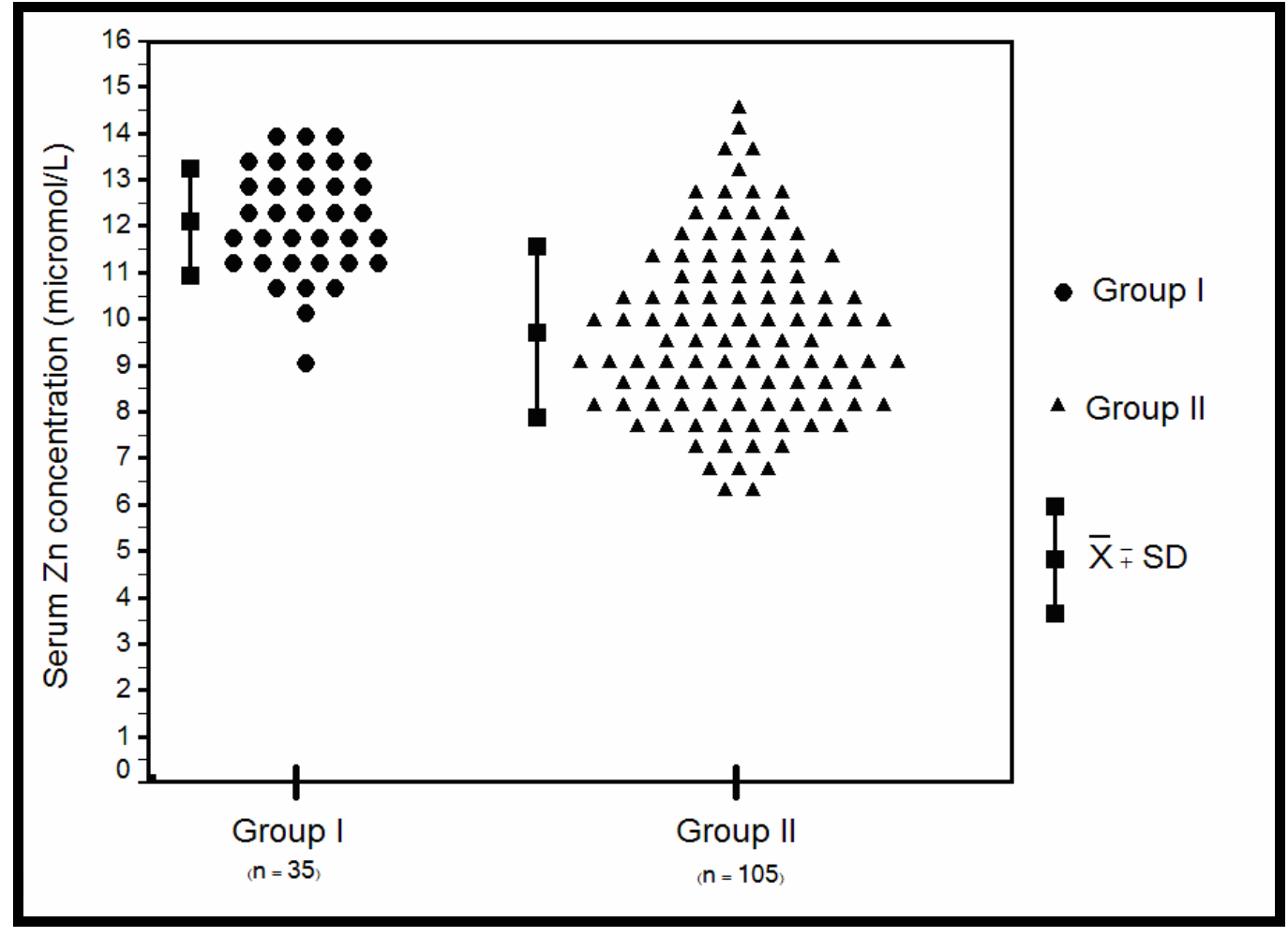

Fig. 1 : Comparison of serum Zn concentration between group I and II.

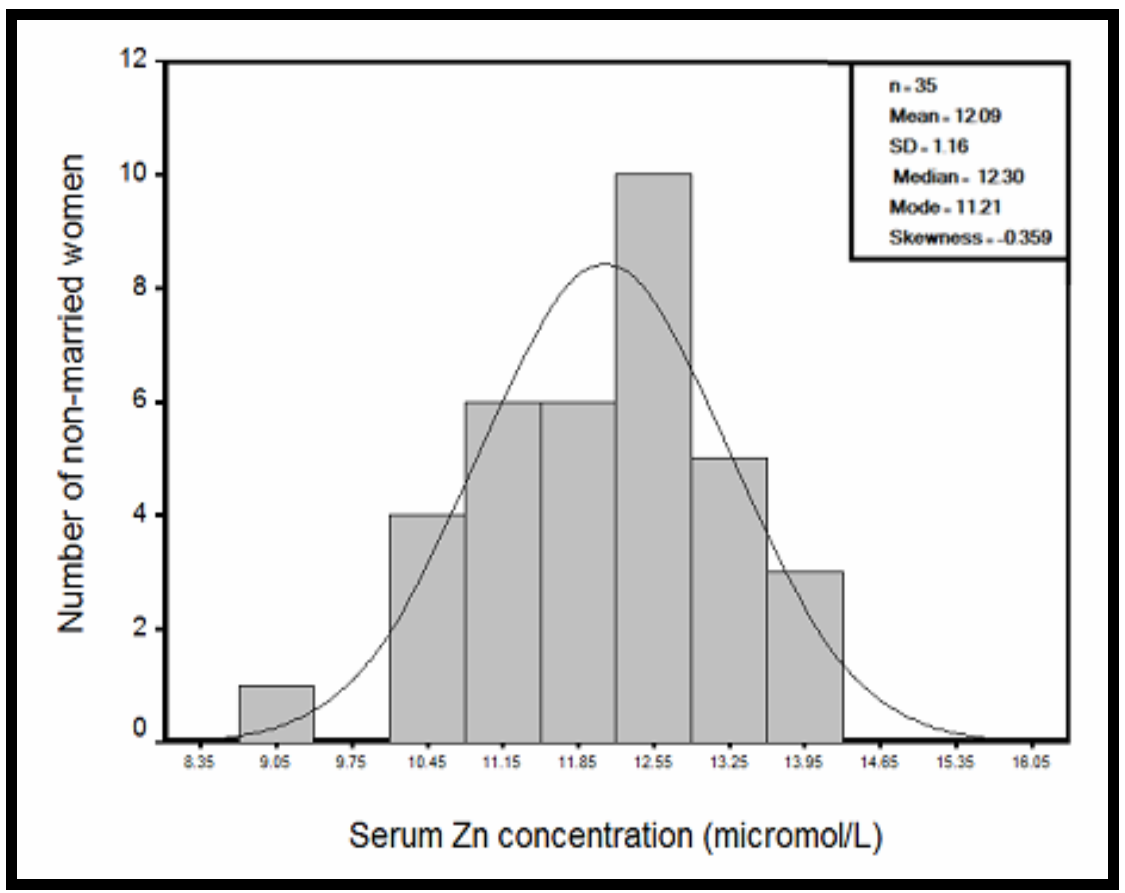

Fig. 2: Distribution of serum Zn concentration in group I. 


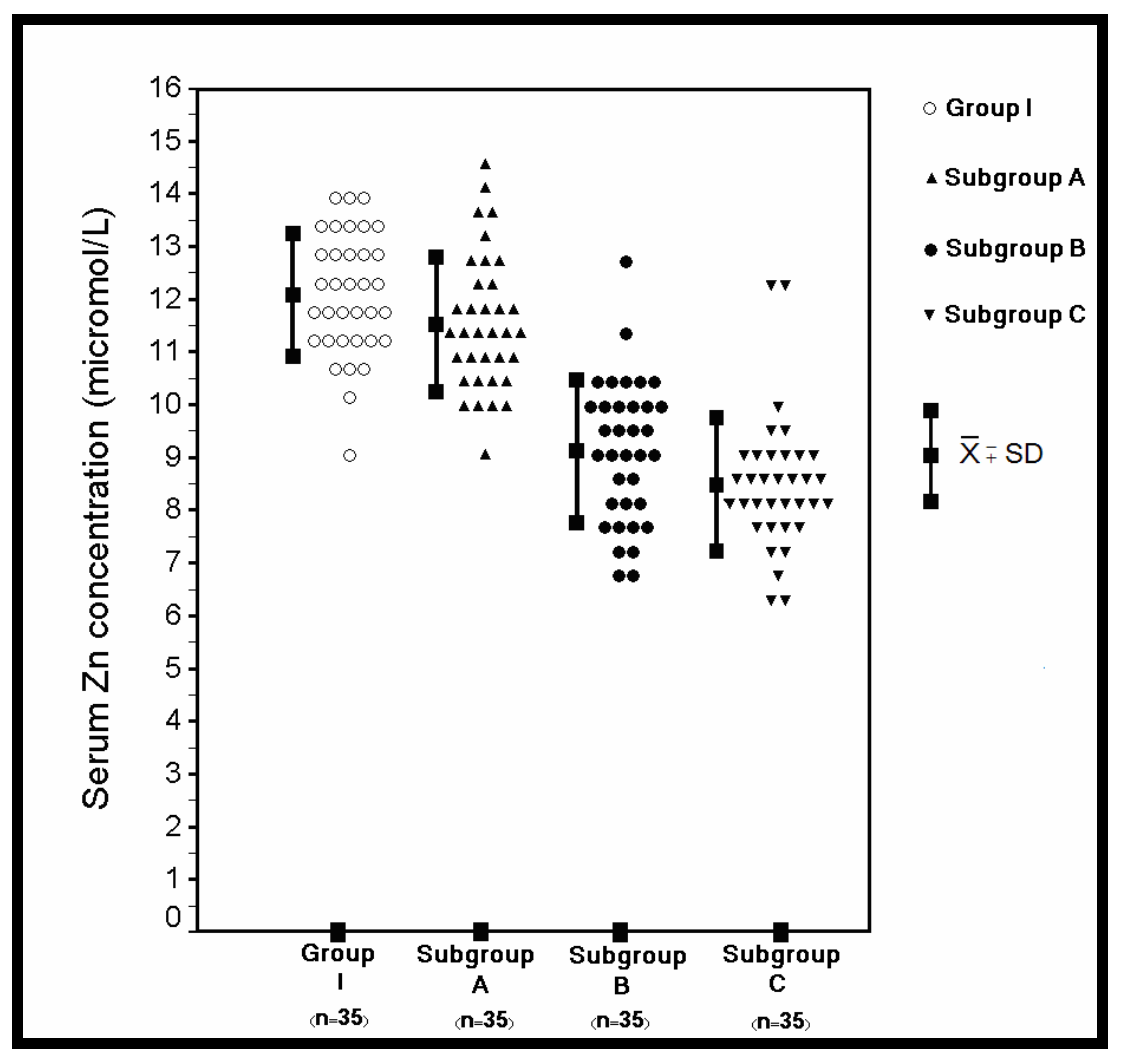

Fig. 3: Comparison of serum Zn concentration between group I and subgroup A,B and C.

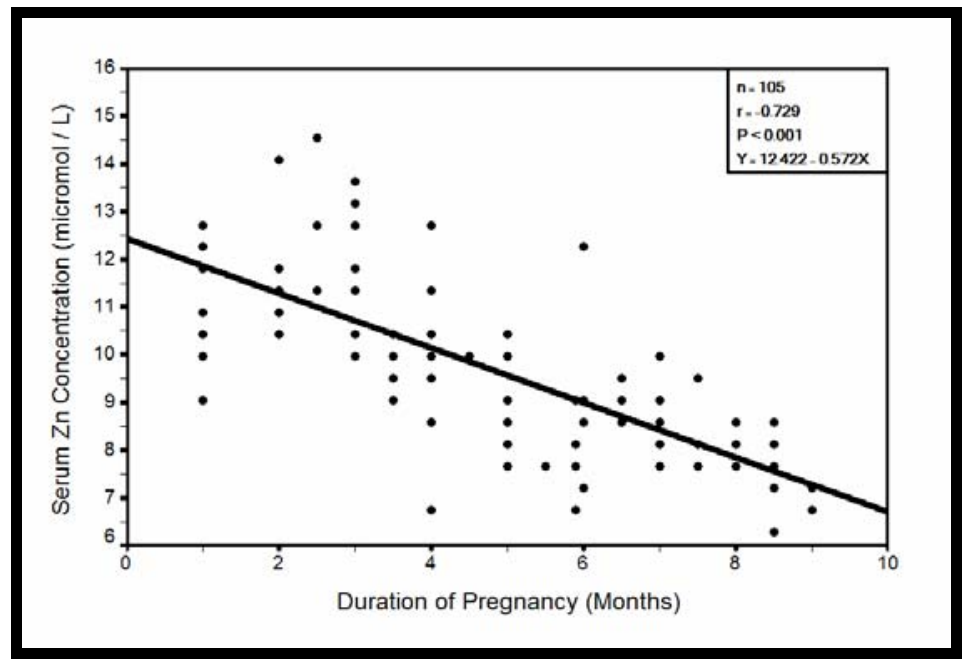

Fig. 4: Correlation between serum Zn and duration of pregnancy in group II. 


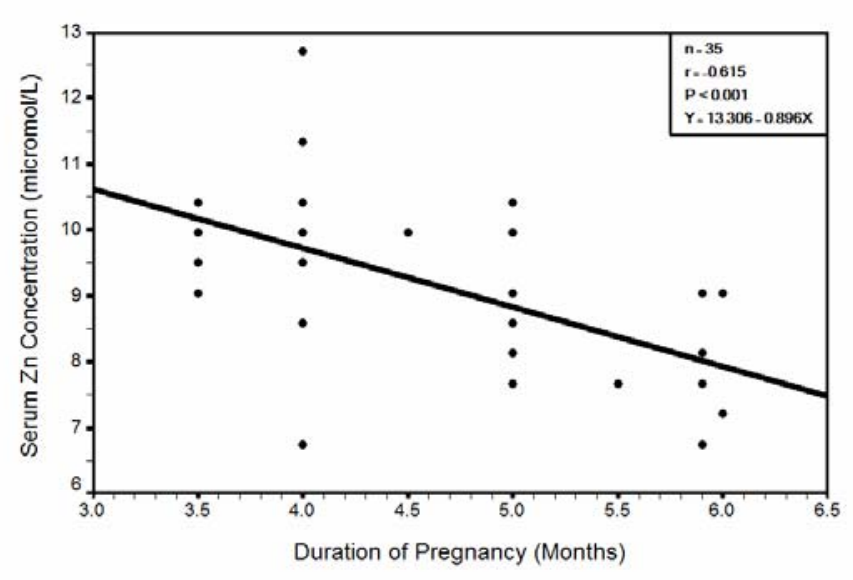

Fig. 5: Correlation between serum Zn and duration of pregnancy in subgroup B

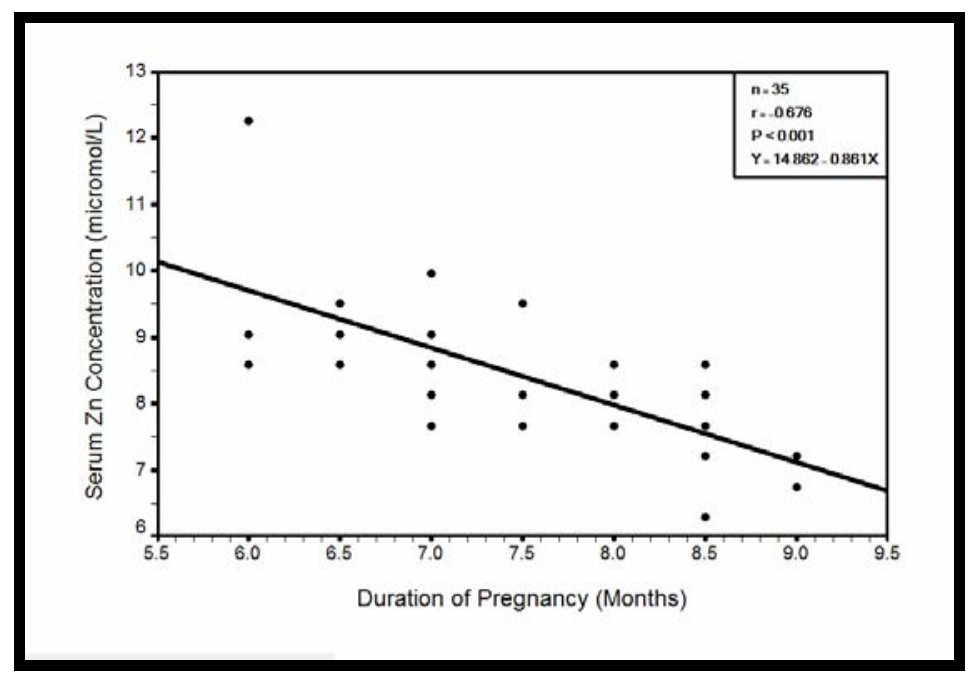

Fig. 6: Correlation between serum Zn and duration of pregnancy in subgroup C.

Serum $\mathrm{Zn}$ is the most widely used index of $\mathrm{Zn}$ status in human (WHO, 2001; Angelova et al., 2006; WHO et al., 2007).In this study serum Zn concentration among apparently healthy non-married women showed a normal distribution pattern (Fig. 2) with the reference range $(\bar{x} \pm 2 S D)$ of $9.78-14.41 \mu \mathrm{mol} / \mathrm{L}$ which lower than the international reference range of 11.6-23.0 $\mu \mathrm{mol} / \mathrm{L}$ obtained by atomic absorption spectrometry method (Akl, 2001).This is probably due to the relatively small sample size used in this study, in addition although the atomic absorption spectrometry method offer greater sensitivity with good analytical parameters and accuracy (Angelova et al., 2006), but it is tedious and subject to numerous interferences (WHO, 2001) and variation in the laboratory estimations (Pathak et al., 2008).

In this study, in comparison with non-married women serum Zn concentration during pregnancy was significantly reduced to reach a value that considered to be Zn deficiency (Burits et al., 2006) (Table 1, 2; Fig 1).This start appearing at the second trimester and continue to decline during the rest of pregnancy (Table 1, 2; Fig 3) and having a significant 
negative correlation with pregnancy duration (Fig 4, 5, 6). These findings are in agreement with other studies that showed high prevalence of $\mathrm{Zn}$ deficiency among pregnant women that may reach up to 64.6\% in the developing world (Shah and Sachdev., 2006; Pathak et al., 2008).Although severe deficiency is rare, it is estimated that mild to moderate deficiency is common (Shah and Sachdev, 2001; Shah and Sachdev, 2006) and serum Zn concentration might reach $35 \%$ below the concentration found in non-pregnant women(Tamura and Goldenberg, 1996). This reduction was correlated with the term of pregnancy(Salimi et al., 2004). The most likely explanations for this phenomenon could be one or more of the following:

i-Heavy demand of $\mathrm{Zn}$ in the developing fetal tissues (Hall and Joseph, 1990; Tamura and Goldenberg, 1996).

ii- Nutritional status during pregnancy (Aydemir et al., 2003; Pathak et al., 2008) that found up to $82 \%$ of the pregnant women world-wide are likely to have inadequate intakes of Zn(Caulfield et al., 1998) requiring increase uptake (Gibson, 2006).

iii- Expanding maternal blood volume (Brown et al., 1985; Ghosh et al., 1985; Yasodhara et al., 1996; Kapoor et al., 1998).

iv- Hormonal changes during pregnancy (Jameson, 1976).

In this study, no significant correlation was found between serum $\mathrm{Zn}$ concentration and the age or number of deliveries, the decline start to appear at the time of ferrous sulphate initiation therapy during second trimester. This finding is in agreement with a previous study which showed that Zn deficiency had no correlation with the number of deliveries but correlated with iron consumption and mother age. This might be explained by the effect of iron in preventing intestinal Zn absorption (Salimi et al., 2004). However, the explanation of mother age correlation is still idiopathic(Salimi et al., 2004) and the difference with this study is probably due to the difference in study location and to a relatively narrow age group selected in this study. Therefore, in this study after exclusion of other factors affecting serum Zn level in both group I and II including age, dietary habit, past-medical, pastsurgical and drug history. The reduction of serum Zn level during pregnancy is mainly attributed to fetal growth demand and ferrous sulphate ingestion.

Observational data relating Zn deficiency to adverse maternal and fetal outcome have produced conflicting results, some studies showed no relation (Tamura et al., 2000; Aydemir et al., 2003; Shah and Sachdev, 2006). Others showed that low maternal serum Zn concentration in pregnancy is associated with pregnancy induced hypertension(Lazebnik et al., 1988; Cherry et al., 1989), abruptio placenta (Kynast and Saling, 1986), inefficient uterine contraction, prolonged or non-progressive labour (Dura-Trave et al., 1984; Lazebnik et al., 1988), maternal hemorrhage and infections(Lazebnik et al., 1988) in addition to fetal malformations (Cavdar et al., 1991) that was reversed by treating the mothers with $\mathrm{Zn}$ antenatally (Brenton et al., 1981). However, a definite conclusion cannot be drawn as to whether the deficiency of Zn alone during pregnancy is teratogenic. The studies are mostly retrospective and have not been well controlled, furthermore, no reliable method of distinguishing mild to moderate Zn deficiency in pregnant women is available (Akl, 2001). Thus, the issue of preventing fetal malformations with $\mathrm{Zn}$ supplementation remains unsolved (Osendarp et al., 2000). It was found that although mothers receiving $\mathrm{Zn}$ supplementation had higher serum $\mathrm{Zn}$ concentration than controls, the maternal $\mathrm{Zn}$ 
concentration remained lower than values reported for well nourished populations. It was concluded that higher doses of $\mathrm{Zn}$ might be needed for further improvement of the maternal Zn status (Caulfield et al., 1999).

In conclusion, since in spite of adequate dietary intake the reduction of serum $\mathrm{Zn}$ level during pregnancy start to appear at second trimester, the time of initiating ferrous sulphate ingestion and continue to decline during the rest of pregnancy and as this reduction is associated with adverse maternal and fetal outcome as proved by studies. Therefore, it is recommended to introduce serum $\mathrm{Zn}$ measurement as a routine test during pregnancy specially from second trimester onward with the use of optimal dose of Zn supplemental therapy.

\section{REFERENCES}

Akl, M.A. (2001). Spectrophotometric and AAS determinations of trace zinc (II) in natural waters and human blood after preconcentration with phenanthraquinone monophenylthiosemicarbazone. Analyt. Sci., 17, 561-564.

Angelova, M.; Nedkova, V.; Yordanova-Laleva, P.; Nicoloff, G.; Alexiev, A. (2006). Level of serum zinc in children with enterocolitis and chronic malabsorption syndrome. Lab. Med., 37(5), 283-285.

Aydemir, F.; Çavdar, A.O.; Söylemez, F.; Cengiz, B. (2003). Plasma zinc levels during pregnancy and its relationship to maternal and neonatal characteristics. Bio. Trace Element Res., 91(3), 193-202.

Bahl, R.; Baqui, A.; Bhan, M.K.; Bhatnagar, S.; Black, R.E.; Brooks, A.; Dutta, P.; Malhotra, S.; Patwari, A.K. (2001). Effect of zinc on clinical course of acute diarrhea. J. Health. Popul. Nutr., 19(4), 338-346.

Brenton, D.P.; Jackson, M.J.; Young, A. (1981). Two pregnancies in a patient with acrodermatitis enteropathica treated with zinc sulphate. Lancet., 318, 500-502.

Brown, C.M.; Ward, R.J.; Haines, A.P.; North, W.R.S.; Abraham, R.; McFayden, I.R. (1985). Zinc and copper in Asian pregnancies - is there evidence for a nutritional deficiency. Br. J. Obstet. Gynaecol., 92, 875- 885.

Burits, C.A.; Ashwood, E.D.; Bruns, D.E. (2006). "Tietz Text Book of Clinical Chemistry and Molecular Diagnostics". 4th edn., Elsevier Saunders Publishing Co USA, pp. 1138-1140.

Caulfield, L.E.; Zavaleta, N.; Figueroa, A. (1999). Adding zinc to prenatal iron and folate supplements improves maternal and neonatal zinc status in a Peruvian population. Am. J. Clin. Nut., 69, 1257-1263.

Caulfield, L.E.; Zavaleta, N.; Shankar, H.; Merialdi, M. (1998). Potential contribution of zinc supplementation during pregnancy to maternal and child survival. Am. J. Clin. Nutr., 68, 499-508.

Cavdar, A.O.; Bahceci, M.; Akar, N.; Erten, J.; Yavuz, H. (1991). Effect of zinc supplementation in a Turkish woman with two previous anencephalic infants. Gynaeco. and Obstet. Invest., 32, 123-125.

Chap, T.L.E. (2003)."Introductory Biostatistics". Wiely interscience., pp. 283-292.

Cherry, F.F.; Sandstead, H.H.; Rojas, P.; Johnson, L.K.; Baston, H.K.; Wang, X.B. (1989). Adolescent pregnancy: associations among body weight, zinc nutriture and pregnancy outcome. Am. J. Clin. Nut., 50, 945-954. 
Dura-Trave, T.; Puig-Abuli, M.; Monreal, I.; Villa-Elizaga, I. (1984). Relation between maternal plasmatic zinc levels and uterine contractility. Gynaeco. and Obstet. Invest., 17, 247-251.

Ghosh, A.; Fong, L.Y.Y.; Wan, C.W.; Liang, S.T.; Woo, J.S.K.; Wong, V. (1985). Zinc deficiency is not a cause for abortion, congenital abnormality and small-forgestational age infant in Chinese women. Br. J. Obstet. Gynaecol., 92, 886-891.

Gibson, R.S. (2006). Zinc: the missing link in combating micronutrient malnutrition in developing countries. Proc. Nutr. Soc., 65(1), 51-60.

Hall; Joseph, St. E. (1990). Plasma zinc levels throughout pregnancy: a study in Jamaican women, with relevant aspects of nutrition . West Indian med. J., 39(1), 17-18.

Hickory, W.; Nanda, R.; Frank, A. (1979). Fetal skeletal malformations associated with moderate zinc deficiency during pregnancy. J. Nutr., 109, 883-891.

Jameson, S. (1976). Effects of zinc deficiency in human reproduction. Acta. Medica. Scandinavica. Supplementum, 593, 4-89.

Joaquim, P. (2007). “Applied Statistics Using SPSS, Statistica, Matlab and R”. 2nd edn. , Springer Company USA., pp. 205-211, 499-451.

Jones, D. (2002). Pharmaceutical statistics. “Pharmaceutical Press”., pp. 25-46.

Kaltenberg, J.; Plum, L.M.; Ober-Blöbaum, J.L.; Hönscheid, A.; Rink, L.; Haase, H. (2010). Zinc signals promote IL-2-dependent proliferation of T cells. Eur. J. Immunol. 40, 1496-1503.

Kapoor, R.K.; Mishra, P.K.; Dixit, S.; Wakhlu, I.; Sharma, B.; Seth, T.D. (1988). Zinc and intrauterine growth. Indian Pediatr., 25, 972-976.

Khachatryan, A.; Nikos, M. (1998). "Biostatistics and Epidemiology". 2nd edn. McGrawHill, pp. 20-23.

Kynast, G.; Saling, E. (1986). Effect of oral zinc application during pregnancy. Gynaeco. and Obstet. Invest., 21, 117-123.

Lazebnik, N.; Kuhnert, B.R.; Kuhnert, P.M.; Thompson, K.L. (1988). Zinc status, pregnancy complications and labour abnormalities. Am J. Obstet. Gynaecol., 158, 161-166.

Michaelsen, K.F.; Samuelson, G.; Graham, T.W.; Lonnerdal, B. (1994). Zinc intake, zinc status and growth in a longitudinal study of healthy Danish infants. Acta. Paediatr., 83, 1115-1121.

Osendarp, S.J.M.; vaan Raaij, J.M.A.; Arifeen, S.E.; Wahed, M.A.; Baqui, A.H.; Fuchs, G.J. (2000). A randomised, placebocontrolled trial of the effect of zinc supplementation during pregnancy on pregnancy outcome in Bangladeshi urban poor. Am. J. Clin. Nut., 71, 114-119.

Pathak, P.; Kapil, U.; Sada, N.; Dwivedi, A.; Singh, R. (2008). Serum zinc levels amongst pregnant women in a rural block of Haryana state, India. Asia Pac. J Clin. Nutr., 17(2), 276-279.

Raman, L.; Shatrugna, V. (2001). Nutrition during pregnancy and lactation. Br. J. Nutr., 85, $193-197$.

Salimi, S.; Yaghmaei, M.; Joshaghani, H.R.; Mansourian, A.R. (2004). Study of zinc deficiency in pregnant women. Iranian J. Publ. Health, 33(3), 15-18.

Sanders, W.B.; Sandstead, H.H. (1991). Zinc deficiency, A public health problem? Am. J. Dischild., 145(8), 853-859. 
Shah, D.; Sachdev, H.P. (2001). Effect of gestational zinc deficiency on pregnancy outcomes: summary of observation studies and zinc supplementation trials. Br. J. Nutr. 85(2), S101-S108.

Shah, D.; Sachdev, H.P. (2006). Zinc deficiency in pregnancy and fetal outcome. Nutr. Rev., 64(1), 15-30.

Shrimpton, R. (2005). Zinc deficiency: what are the most appropriate interventions? BMJ, 330, 347-349.

Tamura, T.; Goldenberg R.L.; Johnston, K.E.; DuBard, M. (2000). Maternal plasma zinc concentrations and pregnancy outcome. Am. J. Clinical Nutrition, 71, 109-113.

Tamura, T.; Goldenberg, R.L. (1996). Zinc nutriture and pregnancy outcome. Nut. Res., 16, 139-181.

WHO/UNICEF/IAEA/ IZiNCG Interagency Meeting on Zinc Status Indicators (2007). Executive summary. Recommendations for indicators of population zinc status. Report of Food Nutr. Bull. , 28, S399-S400.

WHO. (2001). Zinc. Environmental health criteria, 221, Geneva.

Yasodhara, P.; Ramaraju, L.A.; Raman, L. (1996). Trace minerals in pregnancy. Copper and Zinc Nutr. Res., 11, 15-21. 